1995

\title{
Due Process Review Under the Railway Labor Act
}

\author{
Chris Sagers \\ Cleveland-Marshall College of Law, Cleveland State University, c.sagers@csuohio.edu
}

Follow this and additional works at: https://engagedscholarship.csuohio.edu/fac_articles

Part of the Labor and Employment Law Commons

How does access to this work benefit you? Let us know!

\section{Repository Citation}

Sagers, Chris, "Due Process Review Under the Railway Labor Act" (1995). Law Faculty Articles and Essays. 345.

https://engagedscholarship.csuohio.edu/fac_articles/345

This Article is brought to you for free and open access by the Faculty Scholarship at EngagedScholarship@CSU. It has been accepted for inclusion in Law Faculty Articles and Essays by an authorized administrator of EngagedScholarship@CSU. For more information, please contact research.services@law.csuohio.edu. 


\section{HEINONLINE}

Citation: 94 Mich. L. Rev. 466 1995-1996

Content downloaded/printed from

HeinOnline (http://heinonline.org)

Tue May 22 10:37:48 2012

-- Your use of this HeinOnline PDF indicates your acceptance of HeinOnline's Terms and Conditions of the license agreement available at http://heinonline.org/HOL/License

-- The search text of this PDF is generated from uncorrected OCR text.

-- To obtain permission to use this article beyond the scope of your HeinOnline license, please use:

https://www.copyright.com/ccc/basicSearch.do?

\&operation $=$ go\&search Type $=0$

\&lastSearch $=$ simple\&all $=$ on\&titleOrStdNo $=0026-2234$ 


\title{
NOTES
}

\section{Due Process Review Under the Railway Labor Act}

\author{
Christopher L. Sagers
}

\section{INTRODUCTION}

The federal government regulates disputes between organized labor and management in a wide range of private industries. Most disputes are governed by the Labor-Management Relations Act (LMRA), ${ }^{1}$ which both protects the rights of management and organized labor and establishes a comprehensive scheme of dispute resolution. ${ }^{2}$ The Railway Labor Act (RLA), ${ }^{3}$ however, creates a regime unique to the railroad and airline industries. ${ }^{4}$ It requires that certain claims 5 between the covered employers - known in the RLA as "carriers"' - and their employees be settled by submission to the RLA statutory arbitration scheme. Under this scheme, parties must resolve disputes "in the usual manner" where possible. ${ }^{7}$ But where such disputes cannot be resolved by the parties themselves, they must be referred to an arbitral tribunal created by the RLA - the National Railroad Adjustment Board (NRAB). ${ }^{8}$ The NRAB is empowered to delegate its decisionmak-

1. 29 U.S.C. $\S \S 141-88$ (1995).

2. See Florian Bartosic \& Roger C. Hartley, Labor Relations law in the PriVATE SECTOR \& 2.06 ( $2 \mathrm{~d}$ ed. 1986) (detailing the history and purposes of the LMRA).

3. 45 U.S.C. \$§ 151-88 (1988).

4. As initially enacted, the RLA applied to railroads and railroad-owned companies. See 45 U.S.C. $\S 151$ (1988). In 1936, it was amended to include "carriers by air." See 45 U.S.C. $\S 181$ (1988).

5. These include "disputes ... growing out of grievances or out of the interpretation or application of agreements concerning rates of pay, rules, or working conditions." 45 U.S.C. $\S 153(1)(i)$ (1988). "Discharge grievances" are included. See Walker v. Southem R.R., 385 U.S. 196, 198 (1966).

6. 45 U.S.C. $\S 151(1)$ (1988).

7. That is, disputes should be submitted to whatever internal resolution systems may have been set up by the parties, up to and including, the chief operating officer of the carrier designated to handle such disputes. See 45 U.S.C. § 153(1)(i) (1988).

8. Under the Supreme Court's decision in Andrews v. Louisville \& Nashville R.R., 406 U.S. 320 (1972), disputes that are within the jurisdiction of the NRAB may not be heard by state or federal courts but must be referred to the NRAB. See 406 U.S. at 322.

The NRAB is an adjudicative body created by the RLA. It is made up of thirty-four members, half each from labor and from management. It is split into four divisions, each of which has jurisdiction over different classes of employees. Each division is made up also of an equal number of members from labor and management. See 45 U.S.C. $\S 153(1)(h)(1988)$.

Congress amended the RLA in 1934 to add a new tribunal - the National Mediation Board (NMB). The NMB is a panel of three members appointed by the President. See 45 U.S.C. $\$ 154(1)(h)$ (1988). Under the 1934 amendments, the NRAB has jurisdiction over 
ing authority to smaller scale tribunals, ${ }^{9}$ and parties may also voluntarily submit their claims to ad hoc tribunals that operate under RLA rules. ${ }^{10}$

Federal courts disagree about the proper scope of judicial review of RLA tribunals. Specifically, there is a split of authority as to whether courts may reverse RLA rulings for procedural due process violations. ${ }^{11}$ The Fifth Amendment directs that before a fed-

"minor disputes"; that is, interpretation of collective bargaining contracts and individual employee grievances. The NMB mediates all other disputes and conducts elections of labor and management representatives. See BARTOSIC \& HARTLEY, supra note 2, \$ 2.05; RoBERT C. LIEB, LABOR IN THE TRANSPORTATION INDUSTRIES 40-41 (1974).

This Note is not concemed with the constitutional aspects of NMB mediation because it operates under different rules than the NRAB, see 29 C.F.R. $§ \S 1201-03$ (1994), and has a significantly different jurisdiction. When this Note uses the phrase "RLA tribunals" or the like, it should be understood to exclude the NMB.

9. Any division of the NRAB may appoint a panel of two or more of its members to conduct hearings. The final award of such a panel must be made by the entire division. See 45 U.S.C. \& 153(1)(k) (1988). Each division may also establish temporary "regional adjustment boards." Such boards are made up of an equal number of carrier and labor members. They enjoy all the powers of the NRAB division and must observe the same procedural rules and restrictions. See 45 U.S.C. \& 153(1)(x) (1988).

10. The parties to railway or airline labor disputes may voluntarily establish adjustment boards that hear claims specific to the individual carrier, to a system of carriers, or to a particular region. Either party to a dispute under consideration by such a board may remove it to the NRAB. See 45 U.S.C. $\$ \S 153(2), 184$ (1988). The parties also may establish voluntarily a special adjustment board," comprised of one person designated by the carrier and one by labor. See 45 U.S.C. $\$ \$ 153(2)$, 184 (1988).

Finally, if the parties fail to resolve their dispute through conference, submission to the appropriate adjustment board, or through mediation, the dispute may be submitted to an ad hoc board of arbitration. Such a board is composed of three members, two chosen by the parties and the third chosen by the first two members. See 45 U.S.C. $\S 157(1)$-(2) (1988). Such boards operate under a detailed set of procedures applicable only to them. See 45 U.S.C. \& 157(3)(a)-(h) (1988).

The legal significance of the NRAB and each of the inferior tribunals is the same for purposes of this Note. The inferior tribunals are subject to the Due Process Clause. See, e.g., Steffens v. Brotherhood of Ry., Airlines \& S.S. Clerks, 797 F.2d 442, 448-49 (7th Cir. 1986) (agreeing with the district court that a Public Law Board, an inferior arbitral tribunal, was subject to due process); Jones v. St. Louis-San Francisco Ry., 728 F.2d 257, 262 n.4 (6th Cir. 1984) (citing courts holding that lower tribunals are subject to due process). Further, they may be reviewed only on the same grounds as the NRAB. See, e.g., Shafii v. PLC British Airways, 22 F.3d 59, 61 (2d Cir. 1994) (ruling that because an ad hoc arbitrator "occupies the position of the statutorily created NRAB, he or she is subject to the same statutory and constitutional constraints as the NRAB"); Chernak v. Southwest Airlines, 778 F.2d 578, 580 (10th Cir. 1985) (holding that the narrow scope of review of the NRAB is applicable to inferior tribunals); Del Casal v. Eastern Airlines, 634 F.2d 295, 298-99 (5th Cir. 1981) (holding that an airline System Board of Adjustment, an inferior tribunal, may be reviewed only on the same limited grounds as the NRAB). Furthermore, the final decision of such inferior tribunals, except for ad hoc arbitrators governed by 45 U.S.C. $\$ 157$ (1988), is the final decision of the NRAB itself, for "final awards as to any such dispute must be made by the entire [NRAB]." 45 U.S.C. \& 153(1)(k) (1988).

Therefore, this Note will refer to the NRAB and each of the inferior tribunals as "RLA tribunals" or the like.

11. There is no question that RLA tribunals are subject to due process. It is unclear only whether district courts may review RLA proceedings on due process grounds.

Only the government can violate the Due Process Clause. See JoHn E. NowaK \& RONALD D. Rotunda, ConstrTutional LAW $\S 13.5$ (1991). RLA bodies, while private in fact, are public in name and function; their decisions therefore are acts of government. See 
eral actor may deprive a person of "life, liberty, or property," it must first afford that person "due process of law."12 This requirement provides, at a minimum, that the government actor must engage in some formalized procedure to ensure that the deprivation is not the product of government arbitrariness. ${ }^{13}$ The procedural requirements imposed by the due process doctrine traditionally have involved the elaboration of procedural safeguards designed to accord to the individual "the right to be heard before being condemned to suffer grievous loss of any kind" resulting from government action. ${ }^{14}$

In most administrative contexts, there is no question that the decisionmaker is subject to due process scrutiny by reviewing courts. ${ }^{15}$ However, judicial review of RLA administrative findings is "among the narrowest known to the law."16 It is so narrow because the RLA by its language permits a district court to reverse RLA findings only on three grounds: "[F]or failure of the [tribunal]

Shafii, 22 F.3d at 64; Elmore v. Chicago \& Ill. Midland Ry., 782 F.2d 94,96 (7th Cir. 1986). A government actor owes a person due process only when it deprives him of "life, liberty, or property." U.S. Const. amend. V; see also 2 KenNeth Culp Davis \& Richard J. Pierce, ADMINISTRATIVE LAW TREATISE $\$ 9.2$ (1994). Given that an RLA tribunal, under no circumstances, will deprive a person of "life" or "liberty," the applicability of due process turns on whether such a tribunal might deprive a person of "property." Although at least one case explicitly held that the interests at stake in RLA proceedings are "property" for purposes of the Due Process Clause, Nord v. Griffin, 86 F.2d 481, 483 (7th Cir. 1936), the court stated that holding with no analysis, and the case was decided decades before the Supreme Court's revolutionary due process decisions of the 1970s. It is profitable, therefore, to consider current due process jurisprudence. "Property," as defined by the Supreme Court's recent due process decisions, is not limited to rigid, technical forms. It includes interests to which a person is "entitled" under local law; that is, where such an "entitlement" is supported by rules or mutually explicit understandings that may be invoked at a hearing. For instance, in Perry v. Sindermann, 408 U.S. 593 (1972), a public university professor, even though not yet tenured, was held to have a property interest in continued employment because he had been told he had a claim to employment under a "de facto tenure" program. 408 U.S. at 599-603. See generally NowAK \& RoTUNDA, supra, $\$ 13.5$, at 514-15, 519. RLA proceedings are intended to resolve "[t]he disputes between an employee or group of employees and a carrier or carriers growing out of grievances or out of the interpretation or application of agreements concerning rates of pay, rules, or working conditions." 45 U.S.C. \$ 153(1)(i) (1988). To the extent that such "grievances" or "agreements" concern interests of which an employee or carrier has the present enjoyment and an expectation arising from positive law, then those interests are "property" under Sindermann, and due process must be afforded before they can be impaired.

Insofar as there is any question that RLA proceedings must adhere to due process, this Note will assume that they must.

12. U.S. CONST. amend. V; see also NoWAK \& RotUNDA, supra note $11, \S 13.1$.

13. See Laurence H. Tribe, American Constitumonal Law $\$ 10-7$, at 664 (1988) (noting that procedural due process embodies the idea that freedom can only be preserved when institutional checks prevent arbitrary government action).

14. See Joint Anti-Fascist Refugee Comm. v. McGrath, 341 U.S. 123, 168 (1951) (Frankfurter, J., dissenting). See generally TRIBE, supra note 13, § 10-7.

15. See 2 DAvis \& PIERCE, supra note $11, \S 9.1$ (noting that courts apply the due process doctrine to set minimum procedural standards for administrative agencies); 1 CHARLES $H$. Koch, Administrative LaW \& Practice $\$ 7.1$ (1985).

16. Diamond v. Terminal Ry. Ala. State Docks, 421 F.2d 228, 233 (5th Cir. 1970). 
to comply with the requirements of [the RLA], for failure of the [tribunal] to conform, or confine itself, to matters within the scope of [its] jurisdiction, or for fraud or corruption."17

Notwithstanding this narrow language, several federal courts initially considered due process to be an additional basis of review. ${ }^{18}$ In Union Pacific Railroad v. Sheehan, ${ }^{19}$ the Supreme Court called into doubt the validity of these initial holdings. The Sheehan Court reversed a Tenth Circuit finding that the NRAB had violated a litigant's due process rights by refusing to hear one of his legal arguments. Unfortunately, the Court failed to clarify the scope of judicial review in the RLA context, and thus the Courts of Appeals have disagreed about how to interpret the opinion. The Third, ${ }^{20}$ Sixth, ${ }^{21}$ and Eleventh ${ }^{22}$ Circuits hold that the Sheehan decision imposes a bar on due process review. By contrast, the Second, ${ }^{23}$ Fifth, ${ }^{24}$ Seventh, ${ }^{25}$ and Ninth ${ }^{26}$ Circuits regard the Sheehan decision as merely reaffirming that the RLA's narrow scope of review extends to due process violations.

This Note contends that the RLA prohibits due process review and further argues that such a result is constitutional. Part I examines the statutory language of the RLA itself and contends that it limits district court review to the three statutory grounds. Part II argues that the Supreme Court's opinion in Sheehan reaffirms this interpretation because the Court's language unmistakably conveys an intent to bar due process review. Part III explains that such a limitation does not violate the Constitution. The only constitutional provision that could be implicated in an RLA proceeding, the right of procedural due process, is protected by procedures mandated by the RLA. Finally, Part IV argues that this interpretation is desirable because it satisfies the needs of the railroad and airline industries.

17. 45 U.S.C. $\S 153(1)(q)(1988)$.

18. See, e.g., Sheehan v. Union Pac. R.R., 576 F.2d 854, 856 (10th Cir.), revd., 439 U.S. 89 (1978); Kotakis v. Elgin, Joliet \& E. Ry., 520 F.2d 570, 574 (7th Cir.), cert. denied, 423 U.S. 1016 (1975); Hall v. Eastem Air Lines, 511 F.2d 663, 663-64 (5th Cir. 1975); Rosen v. Eastem Air Lines, 400 F.2d 462, 464 (5th Cir. 1968), cert. denied, 394 U.S. 959 (1969); D'Elia v. New York, New Haven \& Hartford R.R., 338 F.2d 701, 702 (2d Cir. 1964), cert. denied, 380 U.S. 978 (1965).

19. 439 U.S. 89 (1978).

20. See United Steelworkers v. Union R.R., 648 F.2d 905, 911-12 (3d Cir. 1981).

21. See Jones v. St. Louis-San Francisco Ry., 728 F.2d 257, 261-62 (6th Cir. 1984).

22. See Henry v. Delta Air Lines, 759 F.2d 870, 873 (11th Cir. 1985).

23. See Shafii v. PLC British Airways, 22 F.3d 59, 61-64 (2d Cir. 1994). 1988).

24. See Hayes v. Westem Weighing \& Inspection Bureau, 838 F.2d 1434, 1436 (5th Cir. 1986).

25. See Steffens v. Brotherhood of Ry., Airline \& S.S. Clerks, 797 F.2d 442, 448 (7th Cir.

26. See Edelman v. Western Airlines, 892 F.2d 839, 845-47 (9th Cir. 1989). 


\section{Plain Language of the RLA}

General principles of statutory construction dictate that an analysis of a statute should begin with the language of the statute itself. ${ }^{27}$ The RLA is unequivocal in its limitation of review to the three statutory grounds. It provides that

the findings and order of the [NRAB] shall be conclusive on the parties, except that the order . . . may be set aside ... for failure of the [NRAB] to comply with the requirements of [the RLA], for failure of the $[N R A B]$ to conform, or confine itself, to matters within the scope of [its] jurisdiction, or for fraud or corruption. ${ }^{28}$

The context of the jurisdictional limitation contains nothing that might suggest that this language means other than what it says. ${ }^{29}$

Indeed, the well-established principle of inclusio unius est exclusio alterius directs that by setting out three permissible bases of review, Congress should be understood to have excluded all others intentionally ${ }^{30}$ For instance, in O'Melveny \& Myers $v . F D I C,{ }^{31}$ the extent of the power of the Federal Deposit Insurance Corporation (FDIC) was questioned. Although the FDIC's functions and powers are set out in great detail in the Financial Institutions Reform,

27. See United States v. Ron Pair Enters., Inc., 489 U.S. 235, 241 (1989); Landreth Timber Co. v. Landreth, 471 U.S. 681, 685 (1985); Bread Political Action Comm. v. Federal Election Commn., 455 U.S. 577, 580 (1982); Dawson Chem. Co. v. Rohm \& Haas Co., 448 U.S. 176, 187 (1980). See generally 2A SUTHERLAND StatuToRy Construction $\S 46.01$ (Noman J. Singer ed., 4th ed. 1984) ("[T] he meaning of the statute must, in the first instance, be sought in the language in which the act is framed, and if that is plain ... the sole function of the courts is to enforce it according to its terms." (quoting Caminetti v. United States, 242 U.S. $470,485(1916)))$.

28. 45 U.S.C. $\S 153(1)(q)(1988)$.

29. The text of 45 U.S.C. $\S 153(1)(q)$ (1988) states in full:

If any employee or group of employees, or any carrier, is aggrieved by the failure of any division of the Adjustment Board to make an award in a dispute referred to it, or is aggrieved by any of the terms of an award or by the failure of the division to include certain terms in such award, then such employee or group of employees or carrier may file in any United States district court in which a petition under paragraph (p) could be filed, a petition for review of the division's order. A copy of the petition shall be forthwith transmitted by the clerk of the court to the Adjustment Board. The Adjustment Board shall file in the court the record of the proceedings on which it based its action. The court shall have jurisdiction to affirm the order of the division, or to set it aside, in whole or in part, or it may remand the proceedings to the division for such further action as it may direct. On such review, the findings and order of the division shall be conclusive on the parties, except that the order of the division may be set aside, in whole or in part, or remanded to the division, for failure of the division to comply with the requirements of this chapter, for failure of the order to conform, or confine itself, to matters within the scope of the division's jurisdiction, or for fraud or corruption by a member of the division making the order. The judgment of the court shall be subject to review as provided in sections 1291 and 1254 of title 28.

30. See 2A SUTHERLAND STATUTORY CONSTRUCtIon, supra note $27, \$ 47.23$ (explaining that where a method of enforcing rights is prescribed in a statute, the method is presumed to be exclusive). The maxim should be applied if the meaning of the statute is plainly expressed in its language and does not produce an absurdity. Id. $\$ 47.25$.

31. 114 S. Ct. 2048 (1994). 
Recovery, and Enforcement Act, 32 the FDIC, as a party to the $O$ 'Melveny action, claimed that its powers could be supplemented or modified by "federal common law." The Supreme Court rejected this argument because, in accordance with the doctrine of inclusio unius, the explicit statutory list of powers barred the creation of new ones. ${ }^{33}$ The RLA similarly sets out a finite list of permissible grounds of review; the doctrine of inclusio unius thus mandates that the list be considered exclusive.

Naturally, courts are particularly cautious where constitutional issues are raised. Courts try to avoid constructions of federal statutes that raise constitutional questions wherever possible. ${ }^{34}$ In fact, in a class of cases in which Congress tried to limit appellate review of constitutional issues, the Court directed that "clear and convincing" evidence of a congressional intent to limit review must be shown. ${ }^{35}$ Such evidence is necessary because a total ban on constitutional review raises "serious constitutional questions."36

The plain language of the RLA, however, presents exactly such clear and convincing evidence that constitutional review is not allowed. If it does not, then hardly any statute imaginable could, for the RLA creates a scope of review which is "amongst the narrowest known to the law."37

\section{Sheehan's Preclusion of Due Process Review}

That the plain language of the RLA precludes due process review was reaffirmed by the Supreme Court in Union Pacific Railroad $v$. Sheehan. ${ }^{38}$ Sheehan involved an employee discharged for violation of internal employee rules who sought to challenge his termination as a breach of his union's collective bargaining agreement. He filed his initial action in state court because at the time it was permissible to challenge a violation of a railroad collective bargaining agreement under state law. But, during the pendency of his claim, the Supreme Court held in Andrews v. Louisville \& Nashville

32. Pub. L. No. 101-73, $\S \S 201-26,103$ Stat. 183, 187-277 (1989) (codified in scattered sections of 12 U.S.C.).

33. $114 \mathrm{~S}$. Ct. at 2054.

34. See, e.g., United States v. X-Citement Video, 115 S. Ct. 464, 472 (1994); Commodity Futures Trading Commn. v. Schor, 478 U.S. 833, 841 (1986); Simpson v. United States, 435 U.S. 6, 12 (1978); Jeffers v. United States, 432 U.S. 137, 155 (1977); International Assn. of Machinists v. Street, 367 U.S. 740, 749 (1961); Crowell v. Benson, 285 U.S. 22, 62 (1932).

35. See, e.g., Webster v. Doe, 486 U.S. 592, 603 (1988); Califano v. Sanders, 430 U.S. 99 , 108-09 (1977); Weinberger v. Salf, 422 U.S. 749, 762 (1975); Johnson v. Robison, 415 U.S. 361, 373-74 (1974).

36. Johnson, 415 U.S. at 366-67; see also Webster, 486 U.S. at 603; Bowen v. Michigan Academy of Family Physicians, 476 U.S. 667, 681 n.12 (1986); Weinberger, 422 U.S. at 762.

37. Diamond v. Terminal Ry. Ala. State Docks, 421 F.2d 228, 233 (5th Cir. 1970).

38. 439 U.S. 89 (1978). 
Railroad $^{39}$ that a railroad employee may only challenge a breach of an agreement covered by the RLA through the NRAB, thereby extinguishing Sheehan's state law claim. Accordingly, he then filed the claim with the NRAB, but the NRAB dismissed his action for failure.to comply with the time limitations set forth in the collective bargaining agreement. Sheehan then brought suit in federal district court, arguing that the time limits under the collective bargaining agreement should have been "tolled" during the pendency of his state law claim, such that the NRAB should be required to hear his claim. The district court, although sympathetic to Sheehan's tolling argument, ${ }^{40}$ felt compelled to uphold the NRAB's order because Sheehan failed to establish any of the three grounds for reversal set forth in the RLA. There was, the court concluded, no "legal principle under which it [could] grant ... relief without violating the [RLA]."41

The Tenth Circuit reversed the district court. The Tenth Circuit pointed out that Sheehan's action had been extinguished only by unfortunate circumstances; if the Supreme Court had not decided Andrews during the pendency of his claim, the claim would have survived. While admitting that review of RLA proceedings is exceedingly narrow, the Tenth Circuit fashioned a broad loophole in the RLA's jurisdictional limitation. The court felt that, in light of the implications arising from Andrews, it was able to review "purely legal issues" raised in RLA hearings. ${ }^{42}$ Although it is unclear exactly what the court meant by "purely legal issues," it apparently meant to refer to legal issues extraneous to the interpretation of collective bargaining agreements, such as the equitable doctrine of the tolling of time limits. Noting that an RLA collective bargaining agreement is a federal contract governed and enforceable by federal law in the federal courts, ${ }^{43}$ the Tenth Circuit concluded that "[t]he applicability of equitable tolling to the agreement in question [was] not in doubt."44 Even so, the court admittedly did not pass on

39. 406 U.S. 320 (1972).

40. The court stated:

Mr. Sheehan argues persuasively that he diligently and in a timely manner pursued one of the two avenues open to him following his discharge, and that it is not in the interests of justice to deny the plaintiff relief simply because he elected to pursue his state court remedies rather than to file an appeal to the $N R A B$ when both alternatives were open to him.

Sheehan v. Union Pac. R.R., 423 F. Supp. 324, 327-28 (D. Utah 1976), revd., 576 F.2d 854 (10th Cir.), revd., 439 U.S. 89 (1978).

41. 423 F. Supp. at 329.

42. Sheehan v. Union Pac. R.R., 576 F.2d 854, 856 (10th Cir.), revd., 439 U.S. 89 (1978).

43. 576 F.2d at 857 (citing Andrews v. Louisville \& Nashville R.R., 406 U.S. 320, 323 (1972)).

44. 576 F.2d at 857. 
the merits of the tolling issue. ${ }^{45}$ Rather, it held that the NRAB's "failure to address the merits of plaintiff Sheehan's claim denied him due process" 46 and remanded to the trial court for further remand to the NRAB.

The Supreme Court reversed the Tenth Circuit. The Court was adamant in its holding that review of RLA proceedings is limited to the three statutory grounds and thus that due process review is inappropriate. It said that "the [RLA] unequivocally states that the 'findings and order of the [NRAB] ... may be set aside only for the three reasons specified therein. We have time and again emphasized that this statutory language means just what it says." 47

That Sheehan limits review to the statutory grounds is further shown by the policy justifications offered by the Court for its holding. The Court said that "[i]n enacting this legislation, Congress endeavored to promote stability in labor-management relations in this important national industry by providing effective and efficient remedies," and part of its scheme for achieving this goal was "to keep [RLA] disputes within the [NRAB] and out of the courts. The effectiveness of the $[\mathrm{NRAB}]$ in fulfilling its task depends on the finality of its determinations." 48 Such finality is lost where litigants may keep RLA disputes indefinitely alive through the timeconsuming process of a due process appeal in the federal courts. ${ }^{49}$

Furthermore, the Sheehan Court expressed open skepticism of the Tenth Circuit's reasoning. It quoted the Tenth Circuit's admission that review of RLA proceedings is "among the narrowest known to the law" but then stated that "[n]onetheless, the court believed it 'possible" " that the scope of review was not so narrow as to proscribe constitutional review.50 "Characterizing the issue presented as one of law ... does not alter the availability or scope of judicial review: the dispositive question is whether the party's objections to the [NRAB's] decision fall within any of the three limited categories of review provided for in the [RLA]." 51 The "issue of law" the Tenth Circuit decided was whether Sheehan received due

45. 576 F.2d at 857 . It could not have done so - for that clearly would be beyond its jurisdiction to review RLA proceedings.

46. 576 F.2d at 856.

47. Union Pac. R.R. v. Sheehan, 439 U.S. 89, 93 (1978) (emphasis added).

48. 439 U.S. at 94 (citations omitted).

49. As to the purposes of the RLA and the policy advantages of limited review, see infra notes 113-20 and accompanying text.

50. 439 U.S. at 91.

51. 439 U.S. at 93 (emphasis added). 
process, ${ }^{52}$ as specifically acknowledged by the Supreme Court. ${ }^{53}$ The Sheehan decision, therefore, holds that the Tenth Circuit's grant to itself of jurisdiction to hear constitutional appeals was improper in light of the statutory limitation.

Some courts, however, have not read Sheehan to bar due process review..$^{54}$ Instead, they contend that the Supreme Court merely held that the Tenth Circuit performed the due process analysis erroneously. These courts defend this interpretation by contending that the Sheehan Court itself applied due process analysis to the case before it. ${ }^{55}$ The Court, they note, stated that:

If the Court of Appeals' remand was based on its view that the [NRAB] had failed to consider [Sheehan's] equitable tolling argument, the court was simply mistaken. The record shows that [Sheehan] tendered the tolling claim to the [NRAB], which considered it and explicitly rejected it. If, on the other hand, the Court of Appeals intended to reverse the [NRAB's] rejection of [Sheehan's] equitable tolling argument, the court exceeded the scope of its jurisdiction to review decisions of the [NRAB].$^{56}$

They assert that, by this language, the Court itself passed on the due process claim, holding that it would only have been a violation of Sheehan's rights if the NRAB had refused to hear the claim. In other words, if the NRAB hears every claim and makes a determination as to its merit, there is no violation; if it refuses to hear a claim, there is a violation.

It could also be argued that in the above quoted language, the Court said that the Tenth Circuit was "simply mistaken" if it thought that the NRAB did not hear Sheehan's tolling argument. ${ }^{57}$ Then the Court said that review on the merits, on the other hand,

52. Sheehan v. Union Pac. R.R., 576 F.2d 854, 856 (10th Cir.) ("We conclude the Board's failure to address the merits of plaintiff Sheehan's claim denied him due process ...."), revd., 439 U.S. 89 (1978).

53. 439 U.S. at 91 (quoting the language quoted supra in note 52).

54. See, e.g., Shafii v. PLC British Airways, 22 F.3d 59 (2d Cir. 1994); Edelman v. Western Airlines, 892 F.2d 839 (9th Cir. 1989); Hayes v. Western Weighing \& Inspection Bureau, 838 F.2d 1434 (5th Cir. 1988); Pacific \& Arctic Ry. \& Navigation Co. v. United Transp. Union, No. 86-4381, 1988 U.S. App. LEXIS 10628 (9th Cir. July 28, 1988); Brotherhood of Maintenance of Way Employees v. St. Johnsbury \& Lamoille County R.R./M.P.S. Assoc., 806 F.2d 14 (2d Cir. 1986); Steffens v. Brotherhood of Ry., Airline \& S.S. Clerks, 797 F.2d 442 (7th Cir. 1986); Del Casal v. Eastern Airlines, 634 F.2d 295 (5th Cir. 1981).

55. See Shafi, 22 F.3d at 64 (stating that the Sheehan Court "initially disposed of the due process violation as nonexistent and then rebuffed the Tenth Circuit for its expansive ruling on their ability to review 'purely legal questions' "); Steffens, 797 F.2d at 449 n.5 ("[The Court] noted that for the [Tenth Circuit] to reject the NRAB's decision in this matter because it disagreed would be to exceed the scope of its review powers. But the Court did not explicitly disapprove of due process as a basis for review." (citation omitted)); see also Edelman, 892 F.2d at 846-47 (stating that Sheehan is completely ambiguous; the RLA is not sufficiently clear and convincing to bar constitutional review).

56. Union Pac. R.R. v. Sheehan, 439 U.S. 89, 92-93 (1978) (citation and footnote omitted).

57. See Shafii, 22 F.3d at 62. 
would "exceed[] the scope of the [Tenth Circuit's] jurisdiction."58 This interpretation might seem to imply that the Tenth Circuit only exceeded its jurisdiction if it attempted to review an argument already considered by the NRAB. Review for a due process violation, by contrast, would be permissible.

Both interpretations of Sheehan fail for several reasons. First, they fail because the Court gave no indication that it was engaging in due process review. The opinion contains no language indicative of due process review and outlines no standards for determining whether an RLA litigant has been afforded sufficient process. In fact, the language quoted above, which supposedly is an application of due process analysis, fails even to use the words "due process."

Second, to understand Sheehan as an application of due process creates a serious imbalance in the opinion. It seems unlikely that the Court would so weakly and ambiguously imply that due process review was appropriate but then heroically announce that review should be no broader than permitted by the statute.

Third, the conclusion that the Sheehan Court applied due process review creates the rather significant problem that what the Court did is simply not due process analysis as we know it. The Court's decisions during the 1970s develop a complex, fact-specific scheme for determining when a litigant has received due process. In Mathews v. Eldridge, ${ }^{59}$ decided only two years before Sheehan, the Court laid out a detailed system for determining whether a given agency's procedural scheme is adequate, ${ }^{60}$ still the dominant test. 61 Mathews requires a reviewing court to balance the gravity of the private interests involved in a given case, reduced by the likelihood of erroneous deprivations of life, liberty, or property, against the social costs of added procedural safeguards. ${ }^{62}$ Yet Sheehan did not even mention Mathews or any of the Court's other due process decisions and engaged in absolutely no discussion of the facts surrounding Sheehan's case.

Therefore, given the unequivocal nature of the Sheehan Court's limitation of review, the language that is claimed to be due process review would be more reasonably understood as classic dictum. The Court merely noted in this language that even if it were within

58. 439 U.S. at 93 (emphasis added).

59. 424 U.S. 319 (1976).

60. 424 U.S. at 335 (explaining the three factors that must be considered in "identification of the specific dictates of due process").

61. See Nowak \& Rotunda, supra note $11, \S 13.8$ ("All courts must now employ the Mathews v. Eldridge balancing test....").

62. 424 U.S. at 335. 
the power of the Tenth Circuit to review for violations of due process, which it is not, no such violation occurred in Sheehan's case.63

\section{Constitutionality of Limited Review}

At first blush, the suggestion that federal courts could be barred from due process review might seem itself to violate the Constitution. The Supreme Court, however, has never held that limitations of constitutional review are themselves unconstitutional. ${ }^{64}$ Indeed, it has repeatedly held that where congressional intent to bar constitutional review is sufficiently clear, constitutional review will be barred, so long as the "serious constitutional questions" thereby raised are answered. 65

The text of the Constitution does not require that anyone have jurisdiction to hear constitutional claims, ${ }^{66}$ and the Court has not yet specified which constitutional questions are "serious" enough to require review. The only question posing a serious potential problem for a jurisdictional limitation in the RLA context is whether the absence of district court review on due process grounds deprives litigants of their right to procedural due process. ${ }^{67}$

63. In addition, some courts raise one other argument. Notwithstanding that the Sheehan Court's limitation of review to the three statutory grounds is absolute and unequivocal, these courts note that it did not explicitly hold that due process review is prohibited. See, e.g., Shafii v. PLC British Airways, 22 F.3d 59, 63 (2d Cir. 1994); Steffens v. Brotherhood of Ry., Airline \& S.S. Clerks, 797 F.2d 442, 448-49 (7th Cir. 1986). However, this argument fails because it would require the Sheehan Court to enumerate every basis of review it intended to prohibit.

64. See McNary v. Haitian Refugee Ctr., 498 U.S. 479, 504 (1991) (Rehnquist, J., dissenting) ("We have never held ... that Congress may not, by explicit language, preclude judicial review of constitutional claims, and ... where that body was obviously interested in expeditiously processing an avalanche of claims ... I think it may do so.").

65. See Webster v. Doe, 486 U.S. 592, 603 (1988) (holding that constitutional review was not barred but only because congressional intent to do so was not sufficiently clear); Califano v. Sanders, 430 U.S. 99, 109 (1977) (stating that "clear and convincing" evidence of congressional intent to bar constitutional review is necessary to overcome the "presumption" of judicial review); Weinberger v. Salfi, 422 U.S. 749, 762 (1975) (stating that clear and convincing evidence is necessary); Johnson v. Robison, 415 U.S. 361, 373 (1974) (same); see also McNary, 498 U.S. at 496 (stating that the rule against bans on constitutional review is only a "presumption"). See generally 3 DAvIS \& PIERCE, supra note $11, \$ 17.9$ (characterizing the rule as only a presumption).

66. See Webster, 486 U.S. at 611 (Scalia, J., dissenting); TRIBE, supra note 13, § 3-5, at 46 (stating that federal court jurisdiction over constitutional questions is not self-executing, and, Marbury notwithstanding, there is not necessarily anything inherent in constitutional law that makes review by the judiciary, as opposed to the other branches, necessary); see also LEARNED HAND, THE BILI OF RIGHTS 1-11 (1958) (stating that the premise of a written constitution would not be disserved if Congress itself judged the constitutionality of its enactments); TRIBE, supra note 13, \& 3-2 (same).

67. The RLA's limitation of review might seem to implicate constitutional constraints other than the procedural due process doctrine. Specifically, limitations of review raise two types of concerns: whether the limitation is within the power of Congress and whether the limitation impairs the rights of individual litigants.

The argument that limitations of review are beyond the power of Congress is easily rejected because Congress has broad discretion to set the jurisdiction of the federal courts. See 
This Part argues that the RLA's procedural safeguards are sufficient to ensure that RLA tribunals satisfy the requirements of the Due Process Clause. Section III.A explains how due process requirements vary according to context and contends that the standard required in RLA proceedings is lower than that in many other administrative contexts. Section III.B asserts that RLA proceedings meet a set of "core" procedural requirements that, given the low due process standard likely required in the RLA context, probably afford sufficient procedural protection such that litigants' due process rights are preserved. Section III.C concludes that even if RLA proceedings were required to meet a higher standard than this core, the RLA assures that its tribunals would meet such requirements.

\section{A. The Due Process Threshold in RLA Proceedings}

In determining whether the RLA's internal procedural safeguards are sufficient to ensure due process, it is necessary to ask what level of process is constitutionally required in the RLA context. Because procedural due process, " 'unlike some legal rules, is not a technical conception with a fixed content unrelated to time, place and circumstances," "68 it is impossible to determine, in the absence of specific facts, exactly what level of process is required.

Ex parte McCardle, 74 U.S. (7 Wall.) 506, 513 (1868); see also 1 JAMES W. MOORE ET AL, Moore's Federal Practice I 0.1, at 2.2-3 (2d ed. 1995); Charles A. Wright, Law of FEDERAL COURTS $\$ 7$ (5th ed. 1994). In accordance with this broad discretion, the Supreme Court has ruled that Congress may retrieve jurisdiction that it has already conferred so long as such retrieval is not for improper purposes, such as to control the outcome of a given litigation. See United States v. Klein, 80 U.S. (13 Wall.) 128, $145-47$ (1871) (Congress may not deny jurisdiction in order to control the outcome of an appeal). Given that the jurisdictional limit at issue here applies to a class of cases and is not in response to a present pending federal proceeding, this concern is not implicated.

The argument that limitation of review might violate the rights of individual litigants fails in light of two realities of RLA litigation. First, the subject matter of RLA proceedings is extremely narrow. RLA proceedings concern only labor-management "grievances" and the interpretation of collective bargaining agreements. See 45 U.S.C. § 153(1)(i) (1988). Thus, only a limited number of constitutional infringements are even possible. It is impossible, for instance, for an RLA tribunal to impair the rights of criminal defendants because RLA hearings are not criminal proceedings. Second, and more importantly, RLA tribunals are of severely limited power. The NRAB has jurisdiction only to hear "disputes between an employee ... and a carrier ... growing out of grievances or out of the interpretation or application of agreements concerning rates of pay, rules, or working conditions." 45 U.S.C. § 153(1)(i) (1988). Its power is restricted to issuing an "award" following a hearing of such disputes. See 45 U.S.C. $\$ 153(1)(n)$ (1988) (empowering the NRAB to make an "award" with respect to disputes within its jurisdiction). A tribunal with such limited power is unlikely to impair individual rights. If, for instance, an RLA tribunal attempted to enjoin an employee from engaging in a certain type of speech, the tribunal would exceed its jurisdiction. It has no power to issue such an order. One of the three permissible bases of review is the failure of the tribunal to confine itself within its jurisdiction. Therefore, if the tribunal attempts to issue an order that would interfere with constitutionally protected rights, a district court normally would be empowered to prevent it.

68. Mathews v. Eldridge, 424 U.S. 319, 334 (1976) (quoting Cafeteria \& Restaurant Workers Union v. McElroy, 367 U.S. 886, 895 (1961)). 
Therefore, the maximum level of process that is likely required in the RLA context should be identified. Then it can be determined whether the RLA's internal procedural standards meet or exceed this maximum.

One can show, as an initial matter, that the maximum procedural standards necessary in RLA hearings probably are lower than in many administrative contexts. In determining the procedural protections necessary in a given area, courts must consider the gravity of the private interests at issue. ${ }^{69}$ The interests involved in RLA proceedings clearly are not so great as to warrant full trial procedure $^{70}$ and, in fact, are less significant than the interests at stake in many other administrative proceedings. For instance, in Goldberg v. Kelly, ${ }^{71}$ the Court considered the rights of a recipient of Aid to Families with Dependent Children (AFDC). Justice Brennan, writing for the majority, noted that "termination of aid ... may deprive an eligible recipient of the very means by which to live .... Since he lacks independent resources, his situation becomes immediately desperate." 72 The Court noted that a welfare recipient is, by hypothesis, destitute and without funds or assets and that to cut off such a person in the face of "brutal need" without a prior hearing of some sort would be unconscionable unless overwhelming considerations justified it. ${ }^{73}$ RLA litigants, by contrast, are, by definition, not recipients of government aid for the unemployed, and, presumably, their situations will not become "desperate" if their claims are decided unfavorably. The employees are most often skilled and able workers who, at the very least, could find other work if their claims in RLA proceedings were unsuccessful. In Arnett $v$. Kennedy, ${ }^{74}$ the Supreme Court was faced with facts similar to those presented in RLA cases. There, a nonprobationary federal employee challenged his termination as a deprivation of due process. The Court refused to find such a deprivation, in part, because the

69. See Mathews, 424 U.S. at 340-43; Cafeteria \& Restaurant Workers Union, 367 U.S. at 895 ("[C]onsideration of what procedures due process may require under any given set of circumstances must begin with a determination of the precise nature of the government function involved as well as of the private interest that has been affected by governmental action."); see also Henry J. Friendly, "Some Kind of Hearing," 123 U. PA. L. REv. 1267, 1278 (1975) (arguing that the required degree of process should vary directly with the protected interests and indirectly with the costs of affording additional procedures).

70. See Mathews, 424 U.S. at 332 (noting that in only one case, Goldberg v. Kelly, 397 U.S. 254, 266-71 (1970), has the Court held that a hearing closely approximating a judicial trial is necessary); see also 1 DAvis \& PierCE, supra note 11, 8.2 (arguing that a full trial could not be required in administrative settings because the burden on administrative bodies would be prohibitive).

71. 397 U.S. 254 (1970).

72. 397 U.S. at 264.

73. See 397 U.S. at 261, (quoting the district court decision, Kelly v. Wyman, 294 F. Supp. 893, 900 (S.D.N.Y. 1968)).

74. 416 U.S. 134 (1974). 
interests of an employee facing discharge were distinguishable from those of the AFDC recipient in Goldberg. ${ }^{75}$ The employee's interests are less significant because, in the event of termination, he may well have independent resources to overcome any temporary hardship and may be able to secure another job. Alternatively, the employee may be eligible for welfare benefits. ${ }^{76}$

Courts also must balance the individual's interests against the government's interests in a given administrative regime. ${ }^{77}$ In the RLA context, the government's interests in efficient, informal decisionmaking are substantial. ${ }^{78}$ The government needs to keep national transportation industries operating efficiently, ${ }^{79}$ and efficiency would be impeded if dispute-resolution procedures in the railroad and airline industries were bogged down by rigid procedural formalities. Thus, the government requires streamlined dispute-resolution mechanisms in the transportation context.

\section{B. "Core” Due Process Requirements}

The flexibility of the due process concept makes it impossible to specify exactly which procedures satisfy the Due Process Clause in the RLA context. However, certain procedural requirements exist that serve so many important functions that their provision by an agency should excuse the absence of the more expensive and timeconsuming procedures in other classes of disputes. ${ }^{80}$ This section argues that the procedures imposed by the RLA on RLA tribunals

75. See 416 U.S. at 154-55; see also Paul R. Verkuil, A Study of Informal Adjudication Procedures, 43 U. CHI. L. REv. 739, 746 (1976).

76. See 416 U.S. at 169 (Powell, J., concurring); Verkuil, supra note 75, at 746. Note as well that the interests at stake in many RLA proceedings will be less significant than those of the discharged employee - as in grievances concerning work rules or contract terms. The loss of employment will be the most severe loss possible in RLA proceedings.

77. See Mathews v. Eldridge, 424 U.S. 319, 334-35 (1976); Cafeteria \& Restaurant Workers Union v. McElroy, 367 U.S. 886, 895 (1961); Friendly, supra note 69, at 1278.

78. See infra notes $115-19$ and accompanying text.

79. See 1971 Railway Labor-Management Dispute Signalman: Hearing on H.R.J. Res. 642 Before the House Comm. on Interstate and Foreign Commerce, 92d Cong., 1st Sess. 5-6 (1971) (stating that a labor dispute involving roughly $2 \%$ of the nation's railroad employees posed a drastic threat to the nation); Railway Labor Dispute: Hearings on H.R. Res. 559 Before the House Comm. on Interstate and Foreign Commerce, 90th Cong., 1st Sess. 2-3 (1967) (observing that a railroad strike would pose disastrous consequences for the war effort and public health); LIEs, supra note 8, at xiv-xvi (arguing that labor disputes in national transportation must be regarded as threats to national well-being).

80. See 1 DAVIS \& PIERCE, supra note $11, \S 9.5$ (relying on Friendly, supra note 69 , at 1279-81, 1291-92). The Supreme Court has enumerated certain specific procedures that might be necessary in various contexts. See Goldberg v. Kelly, 397 U.S. 254, $266-71$ (1970). Unfortunately, the Goldberg Court did not explain how courts should determine which of the listed procedures is necessary in a given case. Drawing heavily upon Goldberg, Judge Friendly compiled and ranked in order of importance a list of eleven procedural requirements, including all those in Goldberg and certain others which have been considered important in the due process analysis. See Friendly, supra note 69, at 1279-95. Professors Davis and Pierce relied upon Judge Friendly's list to suggest that a few of these procedures are 
assure that RLA proceedings satisfy these "core" requirements. Compliance with the RLA's procedural requirements is assured because one of the permissible grounds of review under the RLA is whether the tribunal complied with its provisions. ${ }^{81}$

The first "core" procedure, that the parties appear before an unbiased tribunal, 82 is satisfied by the RLA's structural mechanisms. The RLA requires that the NRAB consist of an equal number of representatives appointed by labor and management. ${ }^{83}$ If the NRAB fails to agree because of a deadlock or the inability to secure a majority vote, it must appoint a neutral person to break the tie.84 The RLA does not explicitly require such proportionality for ad hoc tribunals. However, if the parties elect to submit their dispute to an ad hoc arbitrator that operates under RLA rules, they are responsible for choosing a neutral decisionmaker. Because the choice is theirs, the parties can hardly complain that the government failed to provide a neutral arbitrator and therefore violated their Fifth Amendment rights. Further, if a party is dissatisfied with the chosen arbitrator, it can remove the dispute to the NRAB. ${ }^{85}$

significant enough to constitute "core" due process. See 1 DAvis \& PIERCE, supra note 11, \$ 9.5 .

81. See 45 U.S.C. $\S 153(1)(q)$ (1988).

82. See 2 DAvis \& PIERCE, supra note 11, § 9.5; Friendly, supra note 69 , at 1279.80; Verkuil, supra note 75 , at 750-51.

83. See 45 U.S.C. $\$ \S 153(1)(a)$, (h) (1988).

84. See 45 U.S.C. $§ 153(1)$ (1988). Note that when the NRAB appoints an inferior tribunal, it too will consist of an equal number of labor and management members and is subject to the same rule regarding the appointment of a neutral third-party tie-breaker. See 45 U.S.C. $\S 153(1)(x)(1988)$.

Courts, however, have recognized the potential for collusion between the union and carrier members of an RLA tribunal. See Steffens v. Brotherhood of Ry., Airline \& S.S. Clerks, 797 F.2d 442, 448 (7th Cir. 1986) ("Courts have been sensitive to the potential inequity of requiring employees to "submit their controversy to "a group which is in large part chosen by [the carriers and union representatives] against whom their real complaint is made," and they realize that such collusion between employer and union is a real possibility." (citations omitted)). The courts recognize three means of addressing this problem.

First, if evidence of such collusion is shown, then the injured litigant has grounds to appeal for "fraud or corruption," one of the three permissible bases of review. See Dement v. Richmond, Fredericksburg \& Potomac R.R., 845 F.2d 451, 459 (4th Cir. 1988) (holding that no evidence of fraud had been shown, but implying that if evidence is shown of "a conspiracy to deprive [a litigant] of his contractual rights" then reversal is appropriate).

Second, an employee may prosecute a claim against his union for failing in its duty of fair representation, if the union-representative member(s) of an RLA tribunal is shown to have colluded with the carrier members of the tribunal. See, e.g., Graf v. Elgin, Joliet \& E. Ry., 697 F.2d 771, 779-81 (7th Cir. 1983).

Finally, if the litigant demonstrates that he cannot receive a fair hearing because of collusion or some bias on the part of tribunal members, administrative exhaustion requirements may be excused, and the litigant is entitled to proceed in federal district court. See Glover v. St. Louis-San Francisco Ry. Co., 393 U.S. 324, 330-31 (1969).

85. See 45 U.S.C. $\$ 153$ (1988). 
The second "core" requirement, that a litigant receive notice of the action and grounds asserted for it, ${ }^{86}$ is satisfied by the RLA's notice requirements. Not all means of notice satisfy the Constitution because notice "which is a mere gesture is not due process." 87 However, even in the most formal administrative adjudications, this standard is met by basic "notice pleading," which requires only that a complaint provide sufficient notice of the charges or cause of action. ${ }^{88}$ The methods of notice that are likely to fail due process scrutiny are those that involve mere publication or are so deficient as to be unreasonable. 89 This requirement poses no serious problem for the RLA. Its notice provisions require that the tribunal "shall give [the parties] due notice of all hearings." 90

The third "core" requirement, that the litigant have an opportunity to present reasons why the action should not be taken, ${ }^{91}$ is met by procedural rules promulgated by the $N R A B$ pursuant to its rulemaking power under the RLA. ${ }^{92}$ Under these rules, litigants are required, in a written submission to the NRAB, to "set forth all relevant, argumentative facts, including all documentary evidence submitted in exhibit form."93

86. See 2 DAvis \& PIERCE, supra note 11, § 9.5; Friendly, supra note 69, at 1280-81; Verkuil, supra note 75 , at 750 .

87. Mullane v. Central Hanover Bank \& Trust Co., 339 U.S. 306, 314-15 (1950).

88. See $1 \mathrm{KocH}$, supra note $15, \S 5.3$.

89. In Mullane, a state statute governing the administration of common trust funds provided that notice of litigation concerning the trust could be given to nonresident beneficiaries by publication. The Supreme Court held publication to be constitutionally insufficient in the case of beneficiaries whose names and addresses were known or could be ascertained with reasonable diligence. See 339 U.S. at 314-18. The reasonableness standard of Mullane, which requires that "[t] he means employed must be such as one desirous of actually informing the absentee might reasonably adopt to accomplish it," 339 U.S. at 315, is the keystone of the modern philosophy regarding the notice requirement. See 4 ChIARLES ALAN WrIGHT ET AL, Federal Practice and Procedure \& 1074 (1987).

90. 45 U.S.C. $\S 153(1)(j)(1988)$. At first blush there seems to be the possibility that without due process review, an RLA tribunal would be free to utilize means of notice that would not otherwise satisfy the Due Process Clause. This possibility proves to be virtually nonexistent, however, given that RLA proceedings are in the nature of appeals; all disputes which may be referred to them must first be dealt with "in the usual manner" if possible. See 45 U.S.C. $\& 153(1)(i)$ (1988). The appellate nature of RLA proceedings means that the litigants in any RLA proceeding would have arbitrated the issues and have sufficient familiarity with the facts and circumstances such that a full statement of them in the notice would be redundant. Therefore, any notice of proceedings should be constitutionally sufficient.

91. See 2 DAVIS \& PIERCE, supra note $11, \S 9.5$; Friendly, supra note 69 , at 1281; Verkuil, supra note 75 , at 750 .

92. See 45 U.S.C. $\S 153(1)(v)$ (1988) (empowering the NRAB to make rules of procedure).

93. 29 C.F.R. $\$ 301.5(\mathrm{~d})$-(e) (1994). Although the RLA does not explicitly empower district courts to review RLA tribunals for failure to comply with rules that they themselves promulgate, codified in Chapter 29 of the Code of Federal Regulations, see 45 U.S.C. \& 153(1)(q) (1988), the NRAB may only make procedural rules which are "not in confict with" the RLA. 45 U.S.C. \$ 153(1)(v) (1988). Presumably the RLA would not empower the NRAB to make procedural rules and then give it unchecked authority to disregard them. 
The final "core" requirement, that the parties receive a statement of reasons for the tribunal's decision, ${ }^{94}$ is met by the RLA's written-award requirement. When an RLA tribunal makes a final decision, it is required to state its award in writing and deliver it to the parties.95

\section{Additional Due Process Requirements}

Because due process is a flexible standard, it cannot be said with certainty whether merely meeting the "core" requirements is sufficient. But even if more than the "core" procedural requirements are constitutionally necessary, the procedures used in RLA proceedings still pass constitutional muster because the RLA meets most of the procedural standards that are considered necessary in other contexts.96

First, disclosure of evidence between the parties is among the procedures necessary in some contexts but generally considered less important than the "cores." 97 The NRAB's procedural rules encourage the parties to make a "joint statement of facts." 98 To the extent that opposing evidence is contained in the joint statement, each party obviously is aware of it.

This Note assumes that the district court's power to review compliance with the RLA includes the power to review compliance with NRAB procedural rules.

A litigant's ability to present arguments may be somewhat hampered by the fact that the RLA does not require that tribunals adhere to strict evidentiary requirements. However, due process does not require nearly so exacting an evidentiary standard in the administrative context as in the jury trial context. See Opp Cotton Mills, Inc. v. Administrator of Dept. of Labor, 312 U.S. 126, 155 (1941) ("[I]t has long been settled that the technical rules for the exclusion of evidence applicable in jury trials do not apply to proceedings before federal administrative agencies ...."); Multi-Medical Convalescent \& Nursing Ctr. v. NLRB, 550 F.2d 974, 978 (4th Cir. 1977) (A court may not reverse for the admission of incompetent evidence even though the Federal Rules of Evidence apply to the NLRB "as far as practicable"; the court said "we strongly advise administrative law judges: if in doubt, let it in."); Samuel H. Moss, Inc. v. FTC, 148 F.2d 378, 380 (2d Cir. 1945) (stating that agencies should not apply evidentiary rules strictly). There is no need for an exacting standard because RLA proceedings take place before a panel with some expertise in the area of railroad labormanagement relations, which is less likely than a lay jury to make mistakes concerning the weight and import of the evidence. See generally 2 DAVIS \& PIERCE, supra note $11, \S 10.1$.

94. See 2 DAVIS \& PierCE, supra note $11, \S 9.5$. Only Davis and Pierce suggest that a written decision is clearly a fundamental core requirement. Judge Friendly, however, characterized a statement of reasons as "almost essential" to an appellate system and a useful means of ensuring that agency decisions are carefully considered. See Friendly, supra note 69 , at 1292.

95. See 45 U.S.C. $\$ 153(1)(\mathrm{m})$ (1988).

96. The procedural requirements discussed in the text infra follow are taken from the same sources as the four "cores." See 2 DAVIs \& PIERCE, supra note 11, $\$$ 9.5, at 47.48; NowAK \& RoTUNDA, supra note 11, § 13.8, at 525; Friendly, supra note 69, at 1279-91.

97. See 2 DAvis \& PIERCE, supra note 11, § 9.5; NowAK \& RotundA, supra note 11, $\S 13.8$, at 525; Friendly, supra note 69 , at $1282-83$.

98. See 29 C.F.R. § 301.5(c) (1994). 
Second, recorded proceedings are required in some circumstances. RLA tribunals must make decisions based on recorded proceedings. ${ }^{99}$ Although the RLA contains no explicit requirement that proceedings be recorded, such a requirement can be presumed from the fact that when a decision is appealed, the tribunal must provide the district court with a record of its proceedings. ${ }^{100}$

Third, the assistance of counsel is among the procedures that is required in some cases. ${ }^{101}$ The RLA provides that parties "may be heard . . . by counsel, or by other representatives, as they may respectively elect."102

Fourth, oral hearings are required in some cases. ${ }^{103}$ Although the rules of procedure promulgated by the NRAB pointedly encourage purely written proceedings, the NRAB will grant an oral hearing whenever requested by either party. ${ }^{104}$

Finally, it is sometimes required that a party have an opportunity to confront and cross-examine witnesses or evidence. ${ }^{105}$ The RLA does not meet this final requirement. While nothing in the RLA itself would prevent cross-examination, it is not explicitly contemplated by the statute, and thus the tribunal could not be reversed for its failure to allow it. However, the importance of crossexamination is perhaps overestimated. ${ }^{106}$ Even in jury trials, where cross-examination is considered necessary in order to expose for

99. See 2 Davis \& PIERce, supra note $11, \S 9.5$, at 47 ; Nowak \& Rotunda, supra note $11, \S 13.8$, at 525; Friendly, supra note 69 , at 1291-92.

100. See 45 U.S.C. § 153(1)(q) (1988).

101. See $1 \mathrm{KoCH}$, supra note $15, \S 7.27$, at 583; see also 2 DAvis \& PIERCE, supra note 11 , $\S 9.5$, at 47 ; NowAK \& RoTUNDA, supra note $11, \S 13.8$, at 525; Friendly, supra note 69 , at 1287.

102. 45 U.S.C. $\$ 153(1)(j)$ (1988).

103. See NowaK \& RotUndA, supra note $11, \S 13.8$, at 525 . The importance of this requirement is unclear. Only in the case of Goldberg v. Kelly, 397 U.S. 254 (1970), has the Court held that a trial-type hearing must be held prior to a deprivation of property. See Mathews v. Eldridge, 424 U.S. 319, 340 (1976); 2 Davis \& PIERCE, supra note 11, § 9.3, at 19. Since Goldberg, the emphasis on oral hearings has been somewhat limited by the Court and questioned by commentators. See 2 DAvIS \& PIERCE, supra note 11, $\$ 9.3$ (contending that Goldberg is of limited usefulness because it is distinguishable on its facts from any other context). Written proceedings are sufficient in virtually every other context. See id. As to the importance of the oral hearing requirement, see generally Friendly, supra note 69, at 1281.

104. See 29 C.F.R. § 301.7(a) (1994).

105. See 2 DAvis \& PIERCE, supra note $11, \S 9.5$, at 47 ; NowAK \& Rotunda, supra note $11, \S 13.8$, at 525; Friendly, supra note 69 , at $1285-87$.

106. See Friendly, supra note 69 , at $1284-85$ :

In many such cases the main effect of cross-examination is delay .... Lawyers ... have a vivid recall of the few instances where they destroyed a dishonest witness on crossexamination and forget those where their cross-examination confused an honest one or was ineffective or worse - not to speak of the many cases when they had the good judgment to say "No questions." 
the jury the weaknesses of evidence, 107 it may often be more a hinderance than an asset, due to the risk of injury to the examiner's case. ${ }^{108}$ Furthermore, the emotional power of cross-examination is diminished before expert presiding officers such as NRAB members. ${ }^{109}$ The Administrative Procedure Act, for instance, eschews an unlimited right of cross - it requires only "such crossexamination as may be required for a full and true disclosure of the facts."110 The absence of cross-examination, therefore, does not necessarily violate the Due Process Clause. ${ }^{111}$

In sum, RLA proceedings probably require a relatively low threshold of procedural diligence, and yet the structure of RLA proceedings meets a higher procedural standard. If the RLA tribunal deviates from the procedural scheme of the RLA, it can be reversed. Thus, adequate procedural controls almost surely will be present in RLA proceedings without constitutional review: review on the statutory grounds amounts to de facto due process review. ${ }^{112}$

\section{The Policy GoAls of the RLA}

The limited review suggested by this Note is desirable because it adheres to the RLA's policy of ensuring expeditious dispute resolution. ${ }^{113}$ The RLA is the legacy of the turbulent, prolonged labor struggles of the last decades of the nineteenth century.114 Such con-

107. See 5 John H. Wigmore, Evidence in Trials at Common Law $\$ 1367$, at 32 (Chadbourn rev. ed. 1974) (stating that cross-examination " is beyond any doubt the greatest legal engine ever invented for the discovery of truth").

108. See 1 Richard A. Grvens, Advocacy $\$ 6.01$ (1992) (detailing the potentially adverse effects of cross-examination).

109. See $1 \mathrm{Koch}$, supra note $15, \S 6.25$, at 463 ; E. Barretr Pretryman, Trial by AGENCY 30 (1959) (asserting that cross-examination probably has only "limited usefulness in administrative cases").

110. 5 U.S.C. $\S 556(d)$ (1994).

111. See $1 \mathrm{KoCH}$, supra note $15, \S 6.25$ (stating that the absence of cross-examination does not necessarily violate due process).

112. No court has made such a claim, but one court very nearly did. In Jones v. St. LouisSan Francisco Railway, 728 F.2d 257 (6th Cir. 1984), the Sixth Circuit was faced, on the one hand, with a due process appeal from an RLA tribunal and, on the other, with Sheehan's unequivocal limitation on judicial review. The court held that, even though the appellant had raised the due process appeal forbidden by Sheehan, the "gravam[e]n of [his claim] is that he attacks the award as being improper because the [RLA tribunal] failed to comply with the requirements of the [RLA]." 728 F.2d at 261-62. The court was able to characterize the claim in this way because "certain minimal procedural considerations must be afforded the parties, as Congress so required." 728 F.2d at 263 . The court thus was able to convert a due process claim into a statutory claim, review of which is permitted by the RLA. Although the court did not argue that these "minimal procedural considerations" amounted to the minimum procedural threshold required by the Due Process Clause, it did hold that, in this case at least, the appellant's due process claim was answered adequately by reference to the procedural requirements of the RLA itself.

113. See 45 U.S.C. $\$ 151 \mathrm{a}$ (1988).

114. See Shelton Stromoutst, A Generation of Boomers: The Pattern of RaIL ROAD LABOR CONFLICT IN NiNETEENTH CENTURY AMERICA 274 (1987). 
flict in the transportation industry poses a serious threat to national interests because a functional national transportation industry is necessary to agriculture, industry, defense, and other national concerns. ${ }^{115}$ The principle of finality embodied in the RLA seeks to prevent such a threat. The statute itself announces that its purpose is to "avoid any interruption to commerce or to the operation of any carrier engaged therein [and] to provide for the prompt and orderly settlement of all disputes." 116 This goal can be achieved by the NRAB's informal mechanisms and by the availability of even less formal tribunals inferior to the NRAB. The federal district courts, in contrast, are grindingly slow decisionmakers 117 whose dockets, even without review of administrative agencies, are overflowing. ${ }^{118}$ The task of constitutional litigation often involves intricate factual questions and competing arguments over issues that are not well-settled. Thus, to understand the RLA's jurisdictional limit as allowing due process appeals would frustrate the government's need for an efficient transportation system and impede the RLA's purpose. Sound policy analysis therefore reaffirms the notion that

115. See Emergency Railroad Labor-Management Dispute Legislation - 1970: Hearings on H.J. Res. 1413 and H.J. Res. 1414 Before the House Comm. on Interstate and Foreign Commerce, 91st Cong., 2d Sess. 7-9 (1970) (collecting letters to the House committee from various federal officials detailing the threat to agriculture, defense, communications, etc., posed by ongoing railroad strike); BROTHERHOOD OF RAILrOAD TRAMNEN, THE Pros AND CONS OF COMPULSORY ARBITRATION 65-67 (1965) (detailing the magnitude of national interests involved in the so-called railroad work rules dispute of 1959-65).

116. 45 U.S.C. $\S 151 \mathrm{a}$ (1988).

117. In 1980 , over $40 \%$ of cases pending in the district courts had been ongoing for more than one year. Over $10 \%$ had been ongoing for more than three years. See ADMINISTRATIVE OFFICE OF THE U.S. COURT, FEDERAL JUdictal WORKLOAD STATISTICS 12 (1980). Both the number and percentage of civil cases more than three years old rose each year between 1984 and 1991. See R. Lawrence Dessem, Judicial Reporting Under the Civil Justice Reform Act: Look, Mom, No Cases!, 54 U. PrTr. L. REv. 687, 704-05 (1993). The cost and delay of federal litigation led the Brookings Inst. to complain that "[i]n many courts, litigants must wait for years to resolve their disputes." BROOKINGs INST., JUSTICE FOR ALL: REDUCING COSTS AND Delay IN CrVIL LITIGation 1 (1989) (relying largely on Louss HarRis \& Assoc, ProceDURAI REFORM OF THE CIVIL JUSTICE SYSTEM (1989) (reporting opinion poll finding that a large percentage of judges and lawyers favored reform, including public reporting requirements)). The Institution proposed a comprehensive system of public reporting in federal judicial management which was adopted as the Civil Justice Reform Act of 1990, 28 U.S.C. $\S \S 471-82$ (1990). While early indications are that reporting under the Act may be reducing delay in federal courts, see Dessem, supra, at 706, reform has only begun, and many judges continue to be hopelessly backlogged. Id. at 712 .

118. There are 95 federal district courts, including the District of Columbia, Puerto Rico, the Virgin Islands, the Northem Mariana Islands, and Guam, see 28 U.S.C. \$\$ 81-131 (1992), 48 U.S.C. $\S \S 1424,1611,1694$ (1988), with a total of only 660 active judges, see 28 U.S.C. $\S 133$ (a) (1992). In 1993, approximately 274,300 civil and criminal cases were commenced in the district courts. See U.S. Bureau of THE Census, Statistical Abstract of the United States 211 (1994); see also Richard A. Posner, The Federal CourTs 66 (1985) (showing graphically the "caseload explosion" in the district courts from 1891 to 1983); WRIGHT, supra note $67, \S 1$, at 8 (claiming pressures of docket congestion have led to proposals to reorganize the courts); 13 WRIGHT ET AL., supra note $89, \S 3510$ (observing that recent years have seen a "mad rush" to the federal courts, such that the organization of the courts should be reconsidered in order to accommodate the increased business). 
the plain meaning of the RLA's jurisdiction-limiting language should control, and due process appeals should be prohibited.

One primary fear of a limitation of due process review is that individual employees, who are less able to bear the burdens of litigation than the carriers, will lose the protective scrutiny of the district courts. Without some assurance of minimum procedural standards, it seems that RLA tribunals, either through clumsiness, arrogance, or improper sympathy for the carriers, will abuse the rights of the more vulnerable employees. But as the Sheehan Court noted, finality normally works to the benefit of the employee. ${ }^{119}$ The employee receives a final administrative answer and, if successful, is spared the expense and effort of time-consuming appeals which the carrier can more comfortably bear. To be sure, the principle of finality sometimes works to the employee's detriment. However, evenhanded application of the principle is what the language of the RLA demands. Further, distaste for a limitation of due process review may be somewhat misplaced in the RLA context. In no case will an RLA proceeding deprive a person of life or liberty. While the property interests at stake, namely continued employment and employment terms and working conditions, are less significant than the interests at stake in many other administrative contexts. ${ }^{120}$

\section{CONCLUSION}

The RLA combines an extremely narrow limitation of review with explicit permission to reverse the tribunal for its failure to comply with the provisions of the statute. Its factual context is so narrow and its arbitral tribunal so limited in power that, with the exception of due process, constitutional violations are unlikely. Its provisions ensure a fairly elaborate procedural scheme that almost surely meets any standard that could be required in RLA proceedings. Therefore, the RLA tribunal could be reversed for procedural violations as a matter of simple factual review. Finally, the Supreme Court, upon examining the statute, found clear and convincing evidence that Congress intended to bar constitutional review of RLA decisions. ${ }^{121}$ Given that this is an age in which the

119. See Union Pac. R.R. v. Sheehan, 439 U.S. 89, 94 (1978).

120. Additionally, empirical evidence of the adequacy of administrative procedure is favorable. In Verkuil, supra note 75, Professor Verkuil found that most agencies use procedures that include the "core" procedural safeguards. This may be no final answer to the due process question - after all, the fact that there is usually adequate process does not satisfy the Due Process Clause. However, it does serve to lessen our fears of unchecked government; as noted above, see supra notes 74-76 and accompanying text, the interests at stake in most RLA proceedings will not be monumental, and, at least most of the time, adequate procedural devices are implemented voluntarily by the agencies through their rule-making power.

121. See 439 U.S. at 93-94. 
government simply would collapse if it could not delegate decisionmaking authority to agencies that use informal hearing procedures, ${ }^{122}$ if Congress employs language in a statute implying that the agency's procedural scheme is constitutionally sufficient, there is good reason for courts to defer to that implication.

122. See 1 Davis \& PIERCE, supra note $11, \S 8.2$. 